Board of Governors of the Federal Reserve System

International Finance Discussion Papers

Number 512

June 1995

\title{
EVIDENCE ON NOMINAL WAGE RIGIDITY FROM A PANEL OF U.S. MANUFACTURING INDUSTRIES
}

Vivek Ghosal and Prakash Loungani

NOTE: International Finance Discussion Papers are preliminary materials circulated to stimulate discussion and critical comment. References in publications to International Finance Discussion Papers (other than an acknowledgement that the writer has had access to unpublished material) should be cleared with the author or authors. 


\begin{abstract}
Using annual data for 450 manufacturing industries over the period 1958 to 1989 , we establish the following stylized facts on the response of industry nominal wage growth to aggregate and industry influences:

1. We find support for the canonical wage contracts model outlined in Blanchard and Fischer (1989). The elasticity of response of nominal wage growth to expected inflation is 0.7 . The elasticity of nominal wage growth with respect to changes in unexpected inflation is 0.1 .

2. These elasticity estimates are robust to splitting the sample along various dimensions: level of unionization, durability of the product, and industry contract length. The elasticity of nominal wage growth to expected inflation ranges from 0.6 to 0.8 ; the elasticity with respect to unexpected inflation is between 0.1 and 0.2 .

3. We find support for the multi-sector wage indexation models of Duca and VanHoose (1991) and others. The profit-sharing elasticity (the response of industry wage growth to industry profit growth) is positive, as hypothesized in these models. The instrumental varialsle estimates of the profit-sharing elasticity range from 0.1 to 0.3 .
\end{abstract}




\title{
EVIDENCE ON NOMINAL WAGE RIGIDITY \\ FROM A PANEL OF U.S. MANUFACTURING INDUSTRIES
}

\author{
Vivek Ghosal and Prakash Loungani ${ }^{1}$
}

\section{Introduction}

Understanding why nominal disturbances affect real activity is a central concern in macroeconornic research. The papers by Gray (1976), Fischer (1977), and Taylor (1979) offered a simple explanation for this phenomenon. Essentially, these authors assumed that firms and workers enter into implicit or explicit contracts of the following form: nominal wages are set in advance cof the realization of the nominal disturbance, whereas the level of employment is chosen by the firm, along its labor demand curve, after the realization of the disturbance. Under such contractual agreements, a nominal disturbance--such as an unexpected increase in the price level--lowers real wages and raises employment.

The influence of the "wage contracts" model waned considerably during the 1980's. First, the contractual form assumed in this model was regarded as incompatible with the results from the literature on optimal contracting or risk-sharing between workers and firms. Barro (1977), for instance, argued that it was unlikely that optimal contracts would allow for the costly swings in employment that are generated under the contractual form assumed by the

\footnotetext{
${ }^{1}$ The authors are respectively: economist in the Division of International Finance, Board of Governors of the Federal Reserve System, and Assistant Professor in the Department of Economics, Miami University (Oxford, Ohio). We thank seminar participants at Dartmouth College, the University of Maryland, the Federal Reserve Board, the University of Florida and the Federal Reserve Bank of Atlanta for numerous constructive suggestions. We are grateful to John Duca, Simon Gilchrist, Martha Starr-McCluer and Beth Anne Wilson for detailed comments on the first draft of this paper and to Mark Bils, Danny Blanchflower, George Davis and William Even for useful discussions. Neil Ericsson and Andy Levin helped us a lot with the revisions. We thank Eric Bartelsman and Mark Bils for providing us with the data used in this paper. This paper represents the views of the authors and should not be interpreted as reflecting the views of the Board of Governors of the Federal Reserve System or other members of its staff.
} 
model. Second, the empirical evidence in favor of this model was perceived as weak. In particular, work by Fair (1979) and Mishkin (1982) appeared to overturn Sargent's (1976) finding that unanticipated price movements and real activity were positively correlated. ${ }^{2} \quad$ Third, tests using micro data on contracts [Montgomery and Shaw (1985)] or industry level data [Ahmed (1987)] also offered little support for the predictions of the model.

Recent work, both theoretical and empirical, has been more supportive of the wage contracts model along all these fronts. First, Oswald (1987) and Gottfries (1992) present models in which optimal contracts allow employment to be determined along the labor demand curve. ${ }^{3}$ Second, Gray and Spencer (1992) re-examine the empirical evidence on the relationship between unexpected inflation and real activity. They find that once aggregate supply-side disturbances are carefully controlled for, there is a strong positive correlation between unexpected inflation and real activity, measured either by output or employment. Third, in a detailed study of 1300 Canadian union contracts, Card (1990) finds that unexpected inflation is

\footnotetext{
${ }^{2}$ Another way of stating this empirical failing is that the wage contracts model predicts a negative correlation between real wages and hours, whereas this correlation is close to zero in post-WWII aggregate data. Our view is that this is an empirical failing only if nominal disturbances are assumed to be sole source of fluctuations. If real shocks are assumed to be an equally important influence $\mathrm{cn}$ the real wages-hours correlation, then there is no contradiction between assuming that nominal shocks generate a negative real wages-hours correlation, but that this correlation is pushed towards zero by the impacts of other shocks. Christiano and Eichenbaum (1992) and Kim and Loungani (1992) have a further discussion of this view and Fleischman (1994) presents evidence that is consistent with it.

3 These models make a distinction between two sets of workers at the firm, "insiders" and "outsiders." Insiders enjoy a high degree of job security; for instance, they may be senior workers. Outsiders are workers with a more marginal attachment to the firm. The swings in employment, that Barro found to be implausible under optimal contracting, are borne by outsiders, who have little influence on the form of the contract. See also Waldo (1981), who pointed out that Barro's argument would not hold under the assumptions that "the representative entrepreneur is risk neurral, the representative worker is risk averse, and that the representative worker's income effect dominates his substitution effect (p. 340)."
} 
associated with declines in real wages and increases in employment. ${ }^{4}$

In addition, work by Cho and Cooley (1990), King (1991) and Dutkowsky and Atesoglu (1993)--all of which is based on U.S. aggregate data--suggests that nominal wage and price rigidities may play an important role in the transmission of monetary shocks. ${ }^{5}$

As the above summary of results indicates, these recent tests of the importance of wage contracting rely either on highly aggregated data on the U.S. economy or on micro data on union contracts. Both sources of data have some shortcomings. As discussed by Ahmed (1987) and others, models of monetary non-neutrality often yield observationally equivalent predictions at the aggregate level. The shortcoming of relying on union contracts data is that it does not give us any information on the degree of wage rigidity in sectors or industries where there are "implicit" coritracts. As Hall and Taylor (1991, pgs. 449-50) note, barely $10 \%$ of the U.S. labor force is covered by explicit cost-of-living provisions. The vast majority of workers are therefore covered by implicit, rather than explicit, indexation of wages to price movements. Hall and

4 In related work, Bils (1991) studies the behavior of employment when firms and workers recontract. He argues that if contractual rigidities are important, "then we should observe employment adjustment after recontracting to undo movements in employment during the past contract that were excessive due to rigid wages (p. 1130)." Bils finds evidence in favor of this argument in almost half of the twelve industries he examines. However, wage growth--as measured by average hourly earnings--at the beginning of new contracts appears to be unrelated to the pattern of past employment responses. Bils conjectures that this is because average hourly earnings reflect only part of the total compensation package
that is negotiated during the recontracting.

${ }^{5}$ Dutkowsky and Atesoglu present several tests of the wage contracting model using U.S. aggregate data and conclude that the "wage contracting model ... gives a credible explanation of the U.S. macroeconomy. The findings also provide some support for one-year or five-quarter contracting as the best representation for nominal wage determination in the United States (p. 76)." Cho and Cooley conclude that "nominal price contracts produce data with properties that are inconsistent with the features of the U.S. data, (whereas) nominal wage contracts acting with both technology shocks and monetary shocks produce data that match the features of the U.S. business cycle quite well (pgs. 22-23)." The features that they focus on are the volatilities of various macroeconomic variables and their correlations with one another. King considers a model with monetary shocks only, and finds that models with price rigidity are better at capturing the triangular response pattern in output in response to a money shock. 
Taylor describe wage determination in the non-union sector as follows:

"It is very common for workers who are not in unions to receive wage and salary adjustments once every year. Although there is no formal contract involved it is unlikely that this wage decision will be changed before the next scheduled adjustment period. Hence, the nominal rigidity is very similar to that in the union contracts." (p. 453)

To summarize, despite the fact that union contracts provide relatively high quality micro data on one component of wage indexation, it does not seem reasonable to us to ignore the more informal wage setting behavior outside of the union sector.

In light of the discussion above, we conduct a more broad-based study of nominal wage determination by using data at the 4-digit level of aggregation for 450 manufacturing industries over the period 1958 to 1989 . We attempt to gauge an industry's wage rigidity by measuring how responsive its nominal wage has been to expected and unexpected inflation over our sample period. The use of disaggregated data allows us to control for the impact of industry-specific developments on its wage growth. We are also able to investigate whether the degree of wage rigidity depends on factors such as the level of unionization or the average length of contracts in the industry.

\section{A review of the theory}

We use the illustrative model provided in Blanchard and Fischer (1989) to review the basic features of the wage contracts model. ${ }^{6} \quad$ Let $N_{t}^{d}, N_{t}^{s}, W_{t}$ and $P_{t}$ denote the logarithms of labor demand, labor supply, the nominal wage and the price level, respectively. The labor

\footnotetext{
6 Our discussion is based on Blanchard and Fischer (1989, pgs. 518-525). A complete description of the wage contracts model is given in Gray (1976) and Fischer (1977).
} 
demand and labor supply equations are then expressed as:

$$
\begin{gathered}
N_{t}^{d}=\gamma\left(P_{t}-W_{t}\right)+S_{t} \quad \gamma>0 \\
N_{t}^{s}=\delta\left(W_{t}-P_{t}\right) \quad \delta>0
\end{gathered}
$$

In equation (1), $S_{t}$ is a labor demand shift.

The next two equations describe the assumptions made about wage setting behavior in this economy. Equation (3) states that the nominal wage consists of an expected wage that is set one period in advance, and a second component that reflect the indexation to price surprises.

$$
W_{t}=W_{t}^{e}+\lambda\left(P_{t}-E P_{t}\right) \quad 0 \leq \lambda \leq 1
$$

$E P_{t}$ is the expected price level, and the coefficient $\lambda$ measures the degree of "indexation" to price surprises. To justify the simple form of this equation, Blanchard and Fischer write that "in accordance with reality, indexation (in their model) does not allow wages to respond to other variables than the price level" (p. 523). Equation (4) states that, in each industry, the expected wage is set so as to equate expected labor demand and expected labor supply:

$$
W_{t}^{e} \mid E N_{t}^{d}=E N_{t}^{s}
$$

We can solve for the expected component by substituting (1) and (2) into (4) and taking expectations; then substituting this component in (3) gives the solution for the nominal wage:

$$
W_{t}=E P_{t}+\lambda\left(P_{t}-E P_{t}\right)
$$

The importance of the degree of nominal wage indexation to price surprises can be seen by substituting (5) in (1) to obtain the solution for total hours:

Full indexation to price surprises $(\lambda=1)$ restores the "classical" result that real activity in this 


$$
N_{t}=\gamma(1-\lambda)\left[P_{t}-E P_{t}\right]+S_{t}
$$

economy is invariant to nominal disturbances. When indexation is less than complete $(\lambda<1)$, a price surprise lowers the real wage and raises real activity.

Duca and VanHoose (1991) depart from the one-sector model of Blanchard and Fischer. They consider a multi-sector economy subject to aggregate as well as sector-specific shocks. In their model, the optimal indexation scheme links nominal wages not just to the price level, but also to sectoral profits. ${ }^{7}$ Duca and VanHoose suggest that their optimal indexation scheme is "not inconsistent" with industry-specific wage adjustments such as profit-sharing plans in manufacturing industries.

\section{Specification of the nominal wage equation and description of the data}

\section{(a) Specification}

The form of the estimated equation is shown below: ${ }^{8}$

$$
[\Delta W]_{i, t}=\alpha_{0}[\Delta E P]_{t}+\alpha_{1}[\Delta U P]_{t}+\alpha_{3}[\Delta P R O F]_{i, t}+\alpha_{4}[\Delta M A T]_{i, t}+\mu_{i}
$$

This equation can be thought of as a first-differenced version of the reduced-form solution for nominal wages derived in the previous section [i.e. equation (5) above] in that we are regressing

\footnotetext{
${ }^{7}$ To be more precise, in the Duca-VanHoose model a sector's nominal wage is indexed to a weighted average of the aggregate price level and sector-specific price and productivity. They go on to show that the sum of sectoral price and productivity components is proportional to sectoral profits. Therefore, nominal wages adjust to changes in the aggregate price level as well as sectoral profits.
}

${ }^{8}$ Note that all the variables, W etc., are in logarithms. 
nominal wage growth $\left[\Delta \mathrm{W}_{\mathrm{i}, \mathrm{t}}\right]$ on the change in expected log-prices [ $\left.\Delta \mathrm{EP}_{\mathrm{t}}\right]$ and the change in the unexpected component of log-prices $\left[\Delta U P_{t}\right]$, where $U P_{t}=\left(P_{t}-E P\right)$. For convenience, we will refer to these latter two terms as "expected inflation" and "unexpected inflation", respectively. The equation is augmented by the change in industry profits $\left[\triangle \mathrm{PROF}_{\mathrm{i}, \mathrm{t}}\right]$. As indicated by the review of the relevant theory in the previous section, the questions that we seek to answer through the inclusion of these variables are the following:

(i) does nominal wage growth move one-to-one with expected inflation? [i.e., is $\alpha_{0}=1$ ?]

(ii) does the classical dichotomy hold $\left[\alpha_{1}=1\right]$ ?

(iii) is industry nominal wage growth influenced by industry profitability $\left[\alpha_{3}>0\right]$ ?

Two other terms appear in the wage equation shown above. Changes in industry fuel and raw materials prices $\left[\Delta \mathrm{MAT}_{i, t}\right]$ are included to capture a potentially important source of supply shocks. Industry fixed effects $\left[\mu_{i}\right]$ are included to control for time-invariant factors that may have affected an industry's wage growth over our sample period. Though not shown in the equation above, in the actual estimation we also include lagged wage growth to permit a dynamic response to inflation and the other variables.

\section{(b) Dati}

The results reported in this paper are based on estimating equation (7) with annual data for $450 \mathrm{SIC}$ 4-digit manufacturing industries. The data appendix contains details on sources and variable definitions. The wage variable, $\mathrm{W}$, is production worker nominal wages per hour. The profit measure, PROF, is industry profits-per-worker. The industry cost variable, MAT, is relative industry fuel and material price index. 
Following Card (1990) and Gray and Spencer (1992), we measure the expected component of prices by estimating a forecasting equation for the CPI, and treating the residual from this equation as the unexpected component. In our forecasting equation, the log-level of CPI -- denoted by $P_{t}$-- depends on a linear trend, two lags of itself and two lags of log M2 measure of money. The estimated equation is shown below (standard errors are in parentheses):

\begin{tabular}{|l|l|l|l|l|l|}
\hline \multicolumn{7}{|c|}{ CPI Forecasting Equation } \\
\hline Constant & Time-trend & $\mathrm{P}_{\mathrm{t}-1}$ & $\mathrm{P}_{\mathrm{t}-2}$ & $\mathrm{M} 2_{\mathrm{t}-1}$ & $\mathrm{M} 2_{\mathrm{t}-2}$ \\
\hline-1.55 & -0.03 & 1.63 & -0.90 & 0.21 & -0.31 \\
$(0.27)$ & $(0.007)$ & $(0.09)$ & $(0.09)$ & $(0.11)$ & $(0.11)$ \\
\hline
\end{tabular}

The first difference of the predicted component and the residual from this regression are used as measures of $\Delta \mathrm{EP}_{\mathrm{t}}$ and $\Delta \mathrm{UP}_{\mathrm{t}}$, respectively. For our sample period, the mean (standard deviation) of $\Delta \mathrm{EP}_{\mathrm{t}}$ and $\Delta \mathrm{UP}_{\mathrm{t}}$ are $0.052(0.032)$ and $0.0007(0.015)$, respectively.

As a check on our results, we looked at alternate measures of expected and unexpected inflation that were constructed by Gray and Spencer using a small (4-equation) macro model. Our measures turned out to be fairly similar to their measures, and their use in the empirical work that follows yielded results that are quite close to those reported here. ${ }^{9}$

\section{Some econometric issues}

\section{(a) Endogeneity of inflation and industry profits}

In our regressions, the expected inflation and unexpected inflation terms that appear on the right-hand-side are treated as exogenous. But causality may flow from wage growth to

\footnotetext{
9 An earlier version of this paper contains those results.
} 
inflation as well. Our response to this potential problem is two-fold. First, we note that recent evidence on the direction of causality between aggregate wage growth and inflation suggests that Granger-causality flows from rate of change of prices to wages and not vice versa. For instance, Gordon (1988) concludes that

"the most striking result in this paper is that wage changes do not contribute statistically to the explanation of inflation, with the profound implication that the aggregate supply process in the United States is characterized by a dichotomy: inflation depends on past inflation, not past wage changes." (p. 276)

Mehra (1991) reaches a similar conclusion.

Second, concern about feedback from wage growth to inflation is likely to be more acute in regressions involving aggregate wage growth and inflation. But since our dependent variable is not aggregate wage growth but the industry-specific wage growth in a fairly small (4-digit) industry, endogeneity is unlikely to be a problem.

Of course, we cannot use this argument when it comes to the potential endogeneity of industry profits. Here we correct for the endogeneity bias by using instrumental variables. ${ }^{10}$ The Duca-VanHoose model assumes that there are exogenous shifts in sectoral profits and that these gains are distributed between firms and workers according to some profit-sharing rule. We consider two instruments for industry profits. First, we use variations in military contracts awarded by the Department of Defense as an instrument for exogenous shifts in industry profits. As suggested by Hall (1988), and documented in detail in Rotemberg and Woodford (1992) and

10 The MAT $_{i, t}$ variable could also be subject to endogeneity bias. As we report shortly, the performance of this variable in our regressions is weak, and correcting for endogeneity bias does not
alter this asses sment. alter this assessment. 
Davis, Loungani and Mahidhara (1995), variations in this measure of defense spencling ${ }^{11}$ are driven by shifts in defense policy--which sometimes coincide with wars--rather than by the business cycle; there is little evidence to suggest that variations in a manufacturing industry's wage growth influence defense spending. We include current and lagged values of growth in real defense spending. ${ }^{12}$ Second, we include industry productivity growth as an instrunent. This instrumental variable, unlike defense spending, exhibits cross-industry variation in addition to time-series variation. Current productivity growth is potentially endogenous with respect to wage growth -- our dependent variable. Therefore, we include two lags of industry-specific productivity growth.

As an additional check, we use two alternate sets of instruments. First, we use current and two lags of defense spending growth along with current and two lags of M2 growth--a commonly used proxy for economy-wide demand shifts. Second, the set of time (year) dummies are used as instruments for industry profits. This strategy, which is equivalent to using aggregate manufacturing profits as instruments, is based on the assumption that shocks to wage growth in any particular 4-digit industry are too small to influence aggregate manufacturing profits. Our overall qualitative conclusions are robust to the specific set of instruments used.

\section{(b) Aggregation issues and multi-year contracts}

Our estimation strategy restricts the "indexation" of nominal wages to inflaticn to be the

${ }_{11}$ There is wide variation in defense spending over our sample period; the mean growth rate of real defense spending is about 0.02 , and the minimum and maximum values being approximately -0.09 and 0.25 .

${ }^{12}$ Also see Domowitz, Hubbard and Petersen (1988). Ghosal (1995) contains some results on the impact of defense spending on industry profitability. 
same across industries. While a systematic investigation of cross-industry differences in the degree of indexation is beyond the scope of this paper, we do show that the key parameter estimates are reasonably stable across several broad industry groups.

The first possibility that we investigate is whether indexation depends on the level of unionization in an industry. Freeman and Medoff (1979) report data for 1970 on the fraction of workers in an industry that are unionized. Similar data for part of the 1980's are reported in Curme et al. (1990). ${ }^{13}$ We classify an industry as belonging to the "high" unionization sector as if the level of unionization was higher than the 75th percentile in both 1970 and 1984, while the "low" unionization sector consists of industries where the level was below the 25 th percentile in both years. ${ }^{14}$

The second distinction is based on the length of wage contracts in industries. In the theoretical review, and in the estimated equations, all contracts are assumed to be one year in length. As we stated earlier, our motivation in doing so is that we do not want to ignore the more informal wage contracts--which casual empiricism suggests tend be of one year duration-that prevail outside of the union sector. Nevertheless, we do want to see if the estimates of indexation. that we recover are vastly different in industries that are known to be characterized

${ }^{13}$ Data for this variable are available for three-digit industries only, and hence we are forced to assume that 4-digit industries within a 3-digit aggregate have the same degree of unionization.

${ }^{14}$ Conditioning on two years, one from the 1970's and another from the 1980's, is done to take account of the trend decline in unionization rates over this period. Our results are not sensitive to the particular years that are selected. The 25th, 50th and 75th percentile values of the union variable for 1970 are $0.32,0.45$ and 0.56 , respectively; the corresponding values for 1984 are $0.17,0.26$ and 0.33 , respectively. Therefore, the "low" union sector has a value of 0.32 for 1970 and 0.17 for 1984 . The "high" union sector has values of 0.56 and 0.33 , respectively. While we report results using the 75 th and 25th percentile cutoffs, our overall results were very similar using other reasonable cutoffs to define "high" and "low" union industries. 
by multi-year contracts. To do so we use data on the duration of contracts by industry. ${ }^{15}$ We distinguish industries where the modal contract length is one year from industries where the modal contract length is two (or more) years. ${ }^{16}$

The final sample split we consider is the distinction between industries that produce durable goods and those that produce nondurable goods. Durable goods industries are considerably more cyclical than nondurables, and this allows us to test whether this in fact alters their degree of wage responsiveness. In addition, durable goods industries are often characterized as having higher degrees of unionization and longer contracts (e.g. autornobiles, steel.) than nondurables. Hence looking at the durable versus nondurable split provides another look at the impact of unionization and contract lengths on our estimates.

\section{(c) The long-run relationship between wages, prices and productivity}

The focus of this paper is on the short run response of wages to prices. Nevertheless, neglecting the long run relationship among wages, prices and productivity can sometimes lead to incorrect inferences about the short run behavior. To check if this is the case here, we include two error-correction terms to capture long run relationships. Before we discuss the form of these terms, it is useful to keep in mind that while our dependent variable is nominal wage growth, measures of inflation appear on the right hand side. Hence, by subtracting inflation from both

\footnotetext{
${ }^{15} \mathrm{We}$ are grateful to Mark Bils for providing us with these data, which were originally collected by Wayne Vroman from the BLS publication Current Wage Developments. These data provide information on the length of 2800 contracts signed over the period 1955 to 1985 . The data on contract length are at the SIC 2-digit level. We assumed that all four-digit industries within a two-digit classification have the same contract length.

${ }^{16}$ For the 20 SIC 2-digit industries, the modal contract length was one-year for 3 industries, two-years for 5-industries and three-years for the remaining 12 industries.
} 
sides of the equation, we can reinterpret our equation in terms of real wage growth. We point this out because our discussion of the error-correction terms is phrased in terms of real (rather than nominal) wages.

Following Nymoen (1992), we motivate the inclusion of the error-correction terms heuristically by considering relevant aspects of the firm's maximization problem and the worker's maximization problem separately. The form of the first error-correction term can be motivated using the firm's first-order condition for the choice of labor input: real wages equal marginal product. We label this term as $\mathrm{ECF}_{\mathrm{i}, \mathrm{t}-1}$, and it is equal to $\left[\mathrm{W}_{\mathrm{i}, \mathrm{t}-1}-\mathrm{P}_{\mathrm{i}, \mathrm{t}-1}-\theta_{\mathrm{i}} \mathrm{S}_{\mathrm{i}, \mathrm{t}-1}\right]$, where $\theta_{\mathrm{i}}$ is labor's share in total product in industry $\mathrm{i}$ and $\mathrm{S}$ is the average product of labor (all variables are measured in logarithms). ${ }^{17}$ Our expectation is that the coefficient estimate for ECF should be negative: if real wages exceed the marginal product of labor, wages should decline to restore equilibrium.

The second error-correction term, ECW, comes from considering the workers problem. In the long run, workers can move across industries and this implies that real wages should be equalized across industries. Based on this condition we define $\operatorname{ECW}_{\mathrm{i}, \mathrm{t}-1}$ as $\left[\left(\mathrm{W}_{\mathrm{i}, \mathrm{t}-1}-\mathrm{P}_{\mathrm{i}, \mathrm{t}-\mathrm{l}}\right)\right.$ $\left.\left(W_{t-1}-P_{t-1}\right)\right]$, where the subscripts $i$ denote industry-specific values and the lack of subscripts indicate aggregate values. Here again, the coefficient estimate should be negative, so that a higher-than-average real wage in industry $i$ attracts labor from other industries and thus drives down the real wage.

\footnotetext{
${ }^{17}$ The approximation of the marginal product of labor by $\theta_{i} S_{i, t}$ (measured in levels) would be reasonable if the production function were Cobb-Douglas.
} 


\section{Results}

\section{(a) Results for the entire set of 4-digit industries}

Table 1 presents the cross-industry summary statistics on nominal wage growth $\Delta \mathrm{W}$, growth of profits-per-worker $\triangle \mathrm{PROF}$ and growth of relative fuel and materials prices $\triangle \mathrm{MAT}$. We examine both the mean values and the standard deviation of variables. For instance, the row labelled "S.D. $(\Delta W)$ " presents summary statistics on the standard deviation of industry rominal wage growth. The summary statistics show that there is wide variation in the key cross-industry variables both within-industries over time as well as across-industries.

In Table 2 we present results from estimating several versions of equation (7) using annual data on all 450 4-digit manufacturing industries. While the regressions include 4-digit industry fixed effects, these estimates are not reported. Column (1) has the most general specification. The response of nominal wage growth to expected inflation is about 0.7 . Statistically, this estimate is different from 1 , but in an economic sense one would regard it as being in the neighborhood of the theoretical prediction. The response of nominal wage growth to unexpected inflation is about 0.1 . Clearly, indexation of wages to inflation is far from complete. Taken together, these two results provide strong support for the basic wage cortracting model. $^{18}$

Industry profits growth $\triangle \mathrm{PROF}$ has the expected impact on wage growth, but the implied economic effect is very small; the profit-sharing elasticity is around 0.02 and the estimate is

18 We examined some properties of the error term. First, a White (1980) correction for heteroscedsaticity did not alter any of our qualitative conclusions. Second, we examined the first-order autocorrelation for each industry in the sample. For the vast majority of industries, the autoccrrelation was quite low; the mean value (across industries) was 0.05 , and the 25 th and 75 th percentile values were 0.10 and 0.18 , respectively. 
statistically significant. ${ }^{19}$ The fuels and materials price elasticity is almost always statistically insignilicant. The two error-correction terms have the expected signs and are significant at conventional levels. The estimates of the error-correction terms show that convergence towards long-run relationships is relatively slow.

The results in columns (2) through (4) demonstrate that our quantitative results on the degree of indexation to expected and unexpected inflation are robust to the inclusion or exclusion of particular variables. The estimate of $\triangle \mathrm{EP}$ ranges from 0.65 to 0.71 in these regressions, while the estimate of $\Delta \mathrm{UP}$ hovers around $0.15 .^{20}$

In the regression reported in Column (5) we use instrumental variables to correct for the possible endogeneity of the contemporaneous industry profits variable. The instruments set includes current and two lags of defense spending growth and two lags of industry productivity growth. As shown, the impact on the estimated coefficient of the PROF variable is rather dramatic, a jump from around 0.02 to 0.16 . The other estimates do not change appreciably.

${ }^{19}$ This OLS estimate is comparable to previous findings in the literature. For instance, Blanchflower et al's. (1992) estimates range from 0.02 to 0.04, Estevao and Tevlin (1994) show that the OLS estimate is round 0.05 and Sanfey (1993) reports a profit-sharing elasticity of about 0.05 for the U. S. economy.

${ }^{20}$ We also carried out the following two-step procedure as an additional check. In the first-stage, we regressed industry nominal wage growth on time (year) dummies and the industry-level regressors (i.e., $\triangle \mathrm{PROF}, \triangle \mathrm{MAT}$, lagged wage and the two error-correction terms). In the second-stage we regressed the we regressed the estimates of the time dummies on $\triangle E C P I$ and $\triangle \mathrm{UCPI}$. The coefficient estimate of $\triangle E C P I$ from this second-stage regression was 0.6 , which is very close to the estimates in Table 2 ; the coefficient estimate of $\triangle \mathrm{UCPI}$, while not precisely measured, was essentially zero. Overall, therefore, our finding that the estiniate of $\triangle E C P I$ greatly exceeds the estimate of $\triangle U C P I$ continues to hold. We experimented with alternate specifications for the first-stage regression, dropping the industry-level regressors for instance, and fourd the the estimates of $\triangle \mathrm{ECPI}$ and $\triangle \mathrm{UCPI}$ in the second-stage were not very sensitive to these alterations. 
How sensitive is the estimate of $\triangle \mathrm{PROF}$ to the choice of instruments? The table below shows the various instrument sets that we experimented with and the resulting profit-sharing elasticity.

\begin{tabular}{|l|l|l|l|l|}
\hline \multicolumn{5}{|c|}{ IV Estimates of Profit-Sharing Elasticity } \\
[The estimated regressions contain all the variables shown in Table 1, Column 5] \\
$\begin{array}{l}\text { IV Estimate of } \\
\text { PROF }_{\mathrm{i}, \mathrm{t}}\end{array}$ & $\begin{array}{l}0.179 \\
(0.064)\end{array}$ & $\begin{array}{l}0.167 \\
(0.038)\end{array}$ & $\begin{array}{l}0.385 \\
(0.042)\end{array}$ & $\begin{array}{l}0.110 \\
(0.040)\end{array}$ \\
\hline $\begin{array}{l}\text { Set of } \\
\text { Instruments }\end{array}$ & $\begin{array}{l}\text { Current and two } \\
\text { lags of defense } \\
\text { spending } \\
\text { growth. }\end{array}$ & $\begin{array}{l}\text { Two lags of } \\
\text { industry- } \\
\text { specific } \\
\text { productivity } \\
\text { growth. }\end{array}$ & $\begin{array}{l}\text { Current and two } \\
\text { lags each of } \\
\text { defense } \\
\text { spending and } \\
\text { M2 growth. }\end{array}$ & $\begin{array}{l}\text { Set of year } \\
\text { dummies. }\end{array}$ \\
\hline
\end{tabular}

While the precise number is difficult to pin down, it does appear that correcting for endogeneity delivers a much higher estimate of the profit-sharing parameter than the OLS estimate. ${ }^{21}$

\section{(b) Estimates of indexation by sector}

In the results presented thus far, we have assumed that the response of nominal wage growth to inflation (both expected and unexpected) is the same across all industries. But, as discussed earlier, the degree of indexation may differ across industries because of differences in unionization and other industry characteristics. Hence, we next turn to an investigation of whether our indexation estimates are robust to partitioning our sample into several broad sectors.

21 Estevao and Tevlin (1994) report a similar finding for a much smaller sample of 63 SIC 4-digit manufacturing industries. They use information from the input-output table to create demancl-shift instruments for industry profits. The focus of their work is on testing alternate models of profit-sharing, whereas our investigation is concentrated on tests of the wage contracts model. 
The indexation estimates that we report are based on the specification reported in Column (5) of Table 1. The estimates of indexation by sector reported in Table 3 provide answers to three questions. First, does indexation depends on the level of unionization in the industry? Second, is the degree of indexation in industries where the modal contract length is one year different from that in industries with multi-year contracts? Finally, are there differences between nondurable and durable goods industries? As can be seen by reading across the first two rows of Table 3, the answer to all three questions is generally "no." There are some marginal differences across the various groupings. The sharpest differences lie in the estimate of $\triangle \mathrm{EP}$ between low and high union, and durables versus nondurables. Across all the sample splits, the estimated indexation to expected inflation ranges from about 0.6 to 0.8 , and indexation to unexpected inflation ranges from 0.10 to 0.16 . Overall, these results continue to support the finding of substantial nominal wage rigidity in many broad segments of the U.S. manufacturing sector.

A closer look at the results in Table 2 does reveal some differences across sectors that merit further investigation in future work. The persistence of wage growth is lower in the following sectors: low union, non-durable goods and one-year contracts, as indicated by the estimate of the lagged dependent variable. There is also a quicker reversion to long-run relationships in the sector with one-year contracts (versus multi-year contracts) and in the low union sector (as compared to the high union sector). This is indicated by the larger absolute magnitude of the coefficient estimates on the two error-correction terms. The overall pattern of results .-- a higher persistence of shocks and slower reversion to long-run relationships in industries with multi-year contracts and those that are highly unionized -- appears reasonable. 
On a somewhat lesser scale, this pattern is also evident for the non-durables versus durables split, with the durables sector showing relatively slower reversion to long-run equilibrium and greater persistence of wages.

\section{(c) Estimates of profit sharing by sector}

We also examined whether the estimates of the profit-sharing elasticity, $\triangle \mathrm{PROF}$, differ across the six sample splits. For the union splits, the profit-sharing elasticity is not measured precisely for either group; the point estimate however is much greater for the low union industries. For the other two splits a clearer picture emerges. The profit-sharing elasticity is greater for the non-durables and one-year contracts sectors as compared to the durables and multi-year contracts sectors, respectively. With one exception, the estimates of the profit-sharing elasticity lie in the range 0.08 to 0.21 .

\section{A summing up}

Our findings fall into two broad categories:

\section{Tests of the wage contracts model}

The response of nominal wage growth to expected inflation is approximately 0.7 , an estimate we regard as being in the neighborhood of the basic model's assumption of 1 . This estimate holds for several broad sectors within American manufacturing. The response of nominal wage growth to unexpected inflation ranges from about 0.1 to 0.16 , inclicating considerable departure from the "classical" assumption of full indexation. Our results are consistent with other evidence from micro as well as macro data. In a study of Canadian contract 
data, Prescott and Wilton (1992) find that "ex ante inflation coverage ranges between $60 \%$ and $100 \%$ of expected inflation (p. 331)." Dutkowsky and Atesoglu (1993) estimate the response of aggregate U.S. nominal wage growth to expected inflation to be 0.96 .

\section{Profit-sharing}

The response of wage growth to short-run industry profits is only about 0.02 when the latter are treated as exogenous. Correcting for the endogeneity of industry profits boosts the estimate to between 0.1 and 0.3 , depending on the instrument set used. These findings provide strong support for the multi-sector wage indexation model of Duca and VanHoose in which industry wages respond not just to movements in aggregate inflation but also to variations in sectoral profitability. The empirical findings are broadly consistent with those of Blanchflower, Oswald and Sanfey (1992) and Estevao and Tevlin (1994).

Overall, we view the results as providing support for the wage contracts model as a potential explanation for monetary non-neutrality. Of course, one would like to know how important this channel is relative to the numerous other explanations for monetary non-neutrality. We are pursuing this line of inquiry in our ongoing research. 


\section{Data Appendix}

The source of industry data used in this paper are the Annual Survey of Manufactures and the Census of Manufactures. The data are for 450 SIC 4-digit industries and are over the period 1958-89. See Gray (1990) for details. Data on the Consumer Price Index (CPI), the Producer Price Index (PPI), and the M2 measure of money are from the Economic Report of the President. Below we describe some of the variables used in the paper.

$\mathrm{W}=$ nominal wage per hour.

PROF=[(Total Revenues-Payroll-Materials and Energy Costs)/(Total number of Employees) $]$. MAT $=[($ Industry Energy and Materials Price Index $) /(\mathrm{PPI})]$. 


\section{Table 1}

Summary Statistics

\begin{tabular}{|l|l|l|l|l|}
\hline Variable & Mean & $\begin{array}{l}\text { Standard } \\
\text { Deviation }\end{array}$ & Minimum & Maximum \\
\hline Mean $(\Delta \mathrm{W})$ & 0.055 & 0.009 & -0.025 & 0.174 \\
\hline S.D. $(\Delta \mathrm{W})$ & 0.052 & 0.045 & 0.020 & 0.664 \\
\hline & & & & \\
\hline Mean( $\triangle \mathrm{PROF})$ & 0.034 & 0.020 & -0.019 & 0.213 \\
\hline S.D. $(\Delta \mathrm{PROF})$ & 0.172 & 0.104 & 0.037 & 0.853 \\
\hline & & & & \\
\hline Mean $(\Delta \mathrm{MAT})$ & -0.001 & 0.007 & -0.053 & 0.020 \\
\hline S.D. $(\Delta \mathrm{MAT})$ & 0.030 & 0.019 & 0.009 & 0.124 \\
\hline & & & & \\
\hline
\end{tabular}

Notes:

(i) First, we compute the mean value of each variable (e.g., $\Delta \mathrm{W}$ ) for each industry in the sample. This gives us 450 values, one for each of the 450 industries in the full sample. The row labelled "Mean $(\Delta W)$ ", for instance, presents the cross-industry summary statistics for this variable. For example, the representative industry in the full sample had a mean $\Delta \mathrm{W}$ of $5.5 \%$; the range being from $-2.5 \%$ to $17.4 \%$. (ii) We compute the standard deviation of each variable (e.g., $\Delta W$ ) for each industry in the sample. The row latielled "S.D. $(\Delta \mathrm{W})$ " for instance, presents the cross-industry summary statistics for this variable. The representative industry, therefore, had standard deviation of $\Delta \mathrm{W}$, for instance, of 0.052 ; the range being
from 0.02 to 0.66 . 


\begin{tabular}{|c|c|c|c|c|c|}
\hline $\begin{array}{l}\text { Independent } \\
\text { variables }\end{array}$ & (1) & (2) & (3) & (4) & (5) \\
\hline $\begin{array}{l}\Delta \mathrm{EP}_{\mathrm{t}} \\
\text { expected inflation }\end{array}$ & $\begin{array}{c}0.669 \\
(0.019) \\
\end{array}$ & $\begin{array}{c}0.706 \\
(0.019)\end{array}$ & $\begin{array}{c}0.651 \\
(0.018)\end{array}$ & $\begin{array}{c}0.674 \\
(0.018)\end{array}$ & $\begin{array}{c}0.649 \\
(0.023)\end{array}$ \\
\hline $\begin{array}{l}\Delta \mathrm{UP}_{\mathrm{t}} \\
\text { unexpected inflation }\end{array}$ & $\begin{array}{c}0.109 \\
(0.037)\end{array}$ & $\begin{array}{c}0.159 \\
(0.037) \\
\end{array}$ & $\begin{array}{c}0.111 \\
(0.036)\end{array}$ & $\begin{array}{c}0.146 \\
(0.037)\end{array}$ & $\begin{array}{c}0.118 \\
(0.044)\end{array}$ \\
\hline $\begin{array}{l}\triangle \mathrm{PROF}_{\text {it }} \\
\text { industry profit growth }\end{array}$ & $\begin{array}{c}0.017 \\
(0.002)\end{array}$ & $\begin{array}{c}0.022 \\
(0.003)\end{array}$ & . & . & $\begin{array}{c}0.159 \\
(0.032)\end{array}$ \\
\hline$\Delta \mathrm{PROF}_{\mathrm{i}, \mathrm{t}-1}$ & $\begin{array}{c}0.008 \\
(0.003)\end{array}$ & $\begin{array}{c}0.004 \\
(0.003)\end{array}$ & . & . & $\begin{array}{c}0.008 \\
(0.003)\end{array}$ \\
\hline $\begin{array}{l}\triangle \mathrm{MAT}_{\mathrm{it}} \\
\text { industry fuel and } \\
\text { materials prices }\end{array}$ & $\begin{array}{l}-0.003 \\
(0.015)\end{array}$ & $\begin{array}{c}0.026 \\
(0.015)\end{array}$ & . & . & $\begin{array}{l}-0.009 \\
(0.018)\end{array}$ \\
\hline$\Delta \mathrm{MAT}_{\mathrm{i},-\mathrm{l}}$ & $\begin{array}{l}-0.005 \\
(0.015) \\
\end{array}$ & $\begin{array}{l}-0.016 \\
(0.015) \\
\end{array}$ & . & . & $\begin{array}{l}-0.015 \\
(0.016)\end{array}$ \\
\hline $\begin{array}{l}\Delta \mathrm{W}_{\mathrm{i}, \mathrm{-1}} \\
\text { lagged wage growth }\end{array}$ & $\begin{array}{l}-0.139 \\
(0.009)\end{array}$ & $\begin{array}{l}-0.183 \\
(0.008)\end{array}$ & $\begin{array}{l}-0.137 \\
(0.009)\end{array}$ & $\begin{array}{l}-0.181 \\
(0.009)\end{array}$ & $\begin{array}{l}-0.122 \\
(0.010)\end{array}$ \\
\hline $\begin{array}{l}\mathrm{ECF}_{\mathrm{i}, \mathrm{-1}} \\
\text { error-correction term } \\
\text { [from firm's problem] }\end{array}$ & $\begin{array}{l}-0.051 \\
(0.005)\end{array}$ & . & $\begin{array}{l}-0.051 \\
(0.005)\end{array}$ & . & $\begin{array}{l}-0.052 \\
(0.006)\end{array}$ \\
\hline $\begin{array}{l}\mathrm{ECW}_{\mathrm{i}, \mathrm{t}-1} \\
\text { error-correction term } \\
\text { [from worker's problem] }\end{array}$ & $\begin{array}{l}-0.100 \\
(0.006)\end{array}$ & . & $\begin{array}{l}-0.103 \\
(0.005)\end{array}$ & . & $\begin{array}{l}-0.101 \\
(0.007)\end{array}$ \\
\hline Adj. $R^{2}$ & 0.148 & 0.125 & 0.145 & 0.121 & 0.118 \\
\hline Estimation method & OLS & OLS & OLS & OLS & IV \\
\hline $\begin{array}{l}\text { No. of observations } \\
\text { [no. of industries } \\
\text { x time periods] }\end{array}$ & $\begin{array}{c}12150 \\
{[450 \times 27]}\end{array}$ & $\begin{array}{c}12150 \\
{[450 \times 27]}\end{array}$ & $\begin{array}{c}12150 \\
{[450 \times 27]}\end{array}$ & $\begin{array}{c}12150 \\
{[450 \times 27]}\end{array}$ & $\begin{array}{c}12150 \\
{[450 \times 27]}\end{array}$ \\
\hline & & & & & \\
\hline
\end{tabular}

Note:

(i) The instrument set for the IV estimates (Column 5) consists of current and two lags of defense spending growth, and two lags of industry productivity growth. 


\begin{tabular}{|c|c|c|c|c|c|c|}
\hline \multirow[t]{2}{*}{$\begin{array}{l}\text { Indepenclent } \\
\text { variables }\end{array}$} & (1) & (2) & (3) & (4) & (5) & $(6)$ \\
\hline & $\begin{array}{l}\text { "Low" } \\
\text { level of } \\
\text { union. }\end{array}$ & $\begin{array}{l}\text { "High" } \\
\text { level of } \\
\text { union. }\end{array}$ & $\begin{array}{r}\text { Non- } \\
\text { durable } \\
\text { goods }\end{array}$ & $\begin{array}{r}\text { Durable } \\
\text { goods }\end{array}$ & $\begin{array}{r}\text { One-year } \\
\text { contract } \\
\text { length } \\
\end{array}$ & $\begin{array}{r}\text { Multi-year } \\
\text { contract } \\
\text { length }\end{array}$ \\
\hline$\Delta \mathrm{EP}_{\mathrm{t}}$ & $\begin{array}{c}0.653 \\
(0.114)\end{array}$ & $\begin{array}{c}0.788 \\
(0.046)\end{array}$ & $\begin{array}{c}0.586 \\
(0.036)\end{array}$ & $\begin{array}{c}0.701 \\
(0.029)\end{array}$ & $\begin{array}{c}0.649 \\
(0.068)\end{array}$ & $\begin{array}{c}0.631 \\
(0.023)\end{array}$ \\
\hline$\Delta \mathrm{UP}_{\mathrm{t}}$ & $\begin{array}{c}0.092 \\
(0.165)\end{array}$ & $\begin{array}{c}0.160 \\
(0.085)\end{array}$ & $\begin{array}{c}0.119 \\
(0.070)\end{array}$ & $\begin{array}{c}0.156 \\
(0.053)\end{array}$ & $\begin{array}{c}0.156 \\
(0.133)\end{array}$ & $\begin{array}{c}0.099 \\
(0.043)\end{array}$ \\
\hline$\Delta \mathrm{PROF}_{\mathrm{it}}$ & $\begin{array}{c}0.146 \\
(0.134)\end{array}$ & $\begin{array}{l}-0.011 \\
(0.045)\end{array}$ & $\begin{array}{c}0.181 \\
(0.044)\end{array}$ & $\begin{array}{c}0.078 \\
(0.039)\end{array}$ & $\begin{array}{c}0.214 \\
(0.069)\end{array}$ & $\begin{array}{c}0.106 \\
(0.034)\end{array}$ \\
\hline$\Delta \mathrm{PROF}_{\mathrm{i}, \mathrm{t-1}}$ & $\begin{array}{c}0.011 \\
(0.011)\end{array}$ & $\begin{array}{l}-0.008 \\
(0.005)\end{array}$ & $\begin{array}{c}0.016 \\
(0.005)\end{array}$ & $\begin{array}{c}0.001 \\
(0.004)\end{array}$ & $\begin{array}{c}0.003 \\
(0.009)\end{array}$ & $\begin{array}{c}0.009 \\
(0.003) \\
\end{array}$ \\
\hline$\Delta \mathrm{MAT}_{\mathrm{i}, \mathrm{t}}$ & $\begin{array}{l}-0.069 \\
(0.087)\end{array}$ & $\begin{array}{c}0.000 \\
(0.033)\end{array}$ & $\begin{array}{l}-0.053 \\
(0.023)\end{array}$ & $\begin{array}{c}0.065 \\
(0.028)\end{array}$ & $\begin{array}{l}-0.073 \\
(0.063)\end{array}$ & $\begin{array}{l}-0.013 \\
(0.017)\end{array}$ \\
\hline$\Delta \mathrm{MAT}_{\mathrm{i}, \mathrm{t}-\mathrm{l}}$ & $\begin{array}{c}0.049 \\
(0.016)\end{array}$ & $\begin{array}{l}-0.011 \\
(0.034)\end{array}$ & $\begin{array}{l}-0.004 \\
(0.022)\end{array}$ & $\begin{array}{l}-0.038 \\
(0.027)\end{array}$ & $\begin{array}{c}0.092 \\
(0.062)\end{array}$ & $\begin{array}{l}-0.026 \\
(0.016)\end{array}$ \\
\hline$\Delta \mathrm{WAGE}_{\mathrm{i}, t-1}$ & $\begin{array}{l}-0.260 \\
(0.030)\end{array}$ & $\begin{array}{l}-0.084 \\
(0.026)\end{array}$ & $\begin{array}{l}-0.206 \\
(0.016)\end{array}$ & $\begin{array}{l}-0.049 \\
(0.013)\end{array}$ & $\begin{array}{l}-0.248 \\
(0.027)\end{array}$ & $\begin{array}{l}-0.079 \\
(0.011)\end{array}$ \\
\hline $\mathrm{ECF}_{\mathrm{i}, \mathrm{t}-\mathrm{l}}$ & $\begin{array}{l}-0.162 \\
(0.021)\end{array}$ & $\begin{array}{l}-0.010 \\
(0.013)\end{array}$ & $\begin{array}{l}-0.076 \\
(0.009)\end{array}$ & $\begin{array}{l}-0.037 \\
(0.006)\end{array}$ & $\begin{array}{l}-0.164 \\
(0.020)\end{array}$ & $\begin{array}{l}-0.039 \\
(0.005)\end{array}$ \\
\hline $\mathrm{ECW}_{\mathrm{i}, \mathrm{t}-1}$ & $\begin{array}{l}-0.242 \\
(0.025)\end{array}$ & $\begin{array}{l}-0.047 \\
(0.015)\end{array}$ & $\begin{array}{l}-0.115 \\
(0.010)\end{array}$ & $\begin{array}{l}-0.093 \\
(0.008)\end{array}$ & $\begin{array}{l}-0.213 \\
(0.022)\end{array}$ & $\begin{array}{l}-0.088 \\
(0.007)\end{array}$ \\
\hline Adj. $\mathrm{R}^{2}$ & 0.233 & 0.234 & 0.131 & 0.136 & 0.180 & 0.119 \\
\hline $\begin{array}{l}\text { No. of } \\
\text { observations } \\
\text { [no. of } \\
\text { industries } \\
\text { x time } \\
\text { periods] }\end{array}$ & $\begin{array}{c}4050 \\
{[150 \times 27]}\end{array}$ & $\begin{array}{c}3834 \\
{[123 \times 27]}\end{array}$ & $\begin{array}{c}5238 \\
{[194 \times 27]}\end{array}$ & $\begin{array}{c}6912 \\
{[256 \times 27]}\end{array}$ & $\begin{array}{c}1917 \\
{[71 \times 27]}\end{array}$ & $\begin{array}{c}10233 \\
{[379 \times 27]}\end{array}$ \\
\hline
\end{tabular}

Note: The instrument set consists of current and two lags of growth of defense spending, and two lags of industry productivity growth. 


\section{References}

Ahmed, Shaghil, 1987. "Wage stickiness and the non-neutrality of money: a cross-industry analysis." Journal of Monetary Economics 20 (July), 25-50.

Barro, Robert, 1977. "Long-term contracting, sticky prices and monetary policy." Journal of Monetary Economics 3, 306-16.

Bils, Mark, 1991. "Testing for contracting effects on employment." Quarterly Journal of Economics (November), 1129-1156.

Blanchard, Olivier, and Stanley Fischer, 1989. Lectures on Macroeconomics. The MIT Press.

Blanchflower, David, Andrew Oswald and Peter Sanfey, 1992. "Wages, profits and rent-sharing." NBER Working Paper No. 4222.

Card, David, 1990. "Unexpected inflation, real wages, and employment determination in union cont:acts." American Economic Review 80, 669-88.

Cho, Jang-Ok and Thomas Cooley, 1990. "The business cycle with nominal contracts." Working Paper. Rochester, N.Y.: University of Rochester.

Christiano, Lawrence and Martin Eichenbaum, 1992. "Current real business cycle theories and aggregate labor market fluctuations." American Economic Review.

Curme, Michael, Barry Hirsch and David Macpherson, 1990. "Union membership and contract co'verage in the United States, 1983-1988." Industrial and Labor Relations Review 44, 5-33.

Davis, Steve, Prakash Loungani and Ramamohan Mahidhara, 1995. "Regional Unemployment Cycles," Internal Finance Discussion Paper, Board of Governors of the Federal Reserve System.

Domowitz, Ian, Glenn Hubbard and Bruce Petersen, 1988. "Market Structure and Cyclical Fluctuations in U.S. Manufacturing," Review of Economics and Statistics 70, 55-66.

Duca, John, and David VanHoose, 1991. "Optimal wage indexation in a multisector ecoriomy." International Economic Review 32 (November), 859-67.

Dutkowsky, Donald, and Sonmez Atesoglu, 1993. "Wage contracting in the macroeconomy." Journal of Money, Credit and Banking 25 (February), 62-78.

Estevao, Marcello and Stacey Tevlin, 1994. "The role of profits in wage determination: evidence from U.S. manufacturing." Working Paper, Massachusetts Institute of Technology.

Fair, Ray, 1979. "An analysis of the accuracy of four macroeconometric models." Journal of Political Economy, 87, 701-18.

Fischer, Stanley, 1977. "Long term contracts, rational expectations and the optimal money supply rule." 
Journal of Political Economy, 85, 163-190.

Fleischman: Charles, 1994, "The causes of business cycles and the cyclicality of real wages," University of Michigan working paper, November 1994.

Freeman, Richard, and James Medoff, 1979. "New estimates of private sector unionism in the United States." Industrial and Labor Relations Review 32, 143-74.

Ghosal, Vivek, 1995. "Industry Price-Cost Markup Fluctuations: Role of Energy Price and Monetary Changes," Working Paper, Department of Economics, Miami University.

Gordon, Ro jert, 1988. "The role of wages in the inflation process." American Economic Review Papers and Proceedings (May), 276-283.

Gottfries, Nils, 1992. "Insiders, outsiders and nominal wage contracts." Journal of Political Economy 100 (April), 252-270.

Gray, Jo Anna, 1976, "Wage indexation: a macroeconomic approach." Journal of Monetary Economics 2 (April), 2:1-35.

Gray, Jo Anna, and David Spencer, 1990. "Price prediction errors and real economic activity." Economic Inquiry, 28, 658-681.

Gray, Wayne, 1990. The Productivity Data Base. National Bureau of Economic Research.

Hall, Robert, 1988. "The Relationship between Price and Marginal Cost in U.S. Industry," Journal of Political Eccinomy 96, 921-47.

Hall, Robert, and John Taylor, 1991. Macroeconomics. Norton and Company: New York.

Kim, In-Mor and Prakash Loungani, 1992. "The role of energy in real business cycle models." Journal of Monetary Economics 29, 173-89.

King, Rober:, 1991. "Money and business cycles." Working Paper, University of Rochester.

Mehra, Yash, 1991. "Wage growth and the inflation process." American Economic Review 81, 931-37.

Mishkin, Frederick, 1982. Does anticipated aggregate demand policy matter? American Economic Review, $72,788-802$.

Montgomery, Edward and Kathryn Shaw, 1985. "Long-term contracts, expectations and wage inertia." Journal of Monetary Economics 16 (September), 209-26.

Nymoen, Ragnar, 1992. "Finnish manufacturing wages 1969-1987: real-wage flexibility and hysteresis." Journal of Pclicy Modeling 14(4), 429-451. 
Oswald, Andrew, 1987. "Efficient contracts are on the labour demand curve: theory and facts." Discussion Paper no. 284, London School of Economics, Center for Labour Economics.

Prescott, David and David Wilton, 1992. "The determinants of wage changes in indexed and nonindexed contracts: a switching model." Journal of Labor Economics 10, 331-55.

Rotemberg, Julio, and Michael Woodford, 1992. "Oligopolistic Pricing and the Effects of Aggregate Demand on Economic Activity," Journal of Political Economy 100, 1153-1207.

Sanfey, Peter, 1993. "Wages and Insider-Outsider Models: Theory and Evidence For the U.S.," Working Paper, University of Kent.

Sargent, Thomas J, 1976. "A classical macroeconometric model for the United States." Journal of Political Economy 84 (April), 207-37.

Taylor, John, 1979. "Staggered wage setting in a macro model."American Economic Review 69, 108-111.

Waldo, Douglas, 1981. "Sticky nominal wages and the optimal employment rule." Journal of Monetary Economics 7, 339-353.

White, Halbert, 1980. "A Heteroscedasticity-Consistent Covariance Matrix Estimator and a Direct Test for Heteroscedasticity," Econometrica 48, 817-38. 


\section{International Finance Discussion Papers}

IFDP

Number
Titles

1995

512 Evidence on Nominal Wage Rigidity From a Panel of U.S. Manufacturing Industries

511 Do Taxes Matter for Long-Run Growth?: Harberger's Superneutrality Conjecture

510 Options, Sunspots, and the Creation of Uncertainty

509 Hysteresis in a Simple Model of Currency Substitution

508 Import Prices and the Competing Goods Effect

507 Supply-side Economics in a Global Economy

506 The Lucas Critique In Practice: Theory Without Measurement

505 Real Exchange Rate Targeting and Macroeconomic Instability

504 Inferences from Parametric and Non-Parametric Covariance Matrix Estimation Procedures

503 Exchange-Rate Based Inflation Stabilization: The Initial Real Effects of Credible Plans

502 Strategic Returns to International

Diversification: An Application to the Equity

Markets of Europe, Japan, and North America

501 Real Exchange Rate Movements in High Inflation Countries

500 Political Competition, Casual Relations Between Taxes and Spending, and Their Influence on Government Size: Evidence From State-Level Data
Author(s)

Vivek Ghosal

Prakash Loungani

Enrique G. Mendoza

Gian Maria Milesi-Ferretti

Patrick Asea

David Bowman

Jon Faust

Martin Uribe

Phillip Swagel

Enrique G. Mendoza

Linda L. Tesar

Neil R. Ericsson

John S. Irons

Martin Uribe

Wouter J. Den Haan

Andrew T. Levin

Martin Uribe

John Ammer

Jianping Mei

John H. Rogers

Ping Wang

Diane Lim Rogers

John H. Rogers

Please address requests for copies to International Finance Discussion Papers, Division of International Finance, Stop 24, Board of Governors of the Federal Reserve System, Washington, D.C. 20551. 


\section{International Finance Discussion Papers}

IFDP

Number
Titles

Author(s)

1995

499

498

497

496

495

494

493

\section{Data}

International Stock Price Spillovers and Market Liberalization: Evidence From Korea, Japan, and the United States

How Wide is the Border?

Constrained Suboptimality in Economies with Limited

Communication

Saving-Investment Associations and Capital Mobility On the Evidence from Japanese Regional Data

Convertibility Risk, Default Risk, and the Mexdollar Anomaly

Government Budget Deficits and Trade Deficits Are

Present-Value Constraints Satisfied in Long-Term Data?

Real Shocks and Real Exchange Rates in Really Long-Term

1994

492 Loss Aversion in a Consumption/Savings Model

491 Terms-of-Trade Uncertainty and Economic Growth:

Are Risk Indicators Significant in Growth Regressions

490 Politics, Economics, and Investment: Explaining Plant and Equipment Spending by U.S. Direct Investors in Argentina, Brazil, and Mexico

489 On The Dynamic Properties of Asymmetric Models of Real GNP

488 A distributed block approach to solving near-block-diagonal systems with an application to a large macroeconometric model
Conditional and Structural Error Correction Models

Bank Positions and Forecasts of Exchange Rate Movements
Sang W. Kim

John H. Rogers:

Charles Engle

John H. Rogers;

David Bowman

Robert Dekle

John H. Rogeiss

Shaghil Ahmed

John H. Rogers:

John H. Rogers

David Bowman.

Deborah Minehart

Matthew Rabin

Enrique G. Mendoza

Guy V.G. Stevens
Jon Faust

Ralph Tryon

Neil R. Ericsson

Michael P. Leahy 